\title{
材料強度・構造強度・災害発生の確率モデル
}

\section{Application of Probabilistic Models to Material Strength, Structural Strength and Disaster Occurrence}

\section{まえがき}

信頼性工学は，古くは真空管に起因寸る無線機器の故障低減を目的として始まったといわれている．第 2 次世界大戦後，経 済発展とともに自動車や航空機に代表される多数の機器が社会で利用されるようになった．また，高度成長期以降，鉄道をは じめとする交通機関の拡張，道路や橋梁などの社会基盤の充実が図られている．我々の生活や社会の基盤を支えるあらゆる機 械，土木建築からなる構造物の信頼性，安全性に対寸る認識が深まるとともにその重要性が再認識されるようになり，信頼性 工学が担うべき役割も増している.

信頼性とは，「アイテムが与えられた条件の下で，与えられた期間，要求機能を遂行できる性質」として JIS に定義されてい る. その実現のための科学的理論と応用に関する研究が信頼性工学で探求・議論されている領域である. 構造物を構成する材 料や部品からなる製品・構造物の信頼性を如何に保証するかについて，技術革新や適応領域の拡大とともに理論的検証や適用 方法が考案されている，構造物へはたらきかける人間要素も含めた系を対象にした人間信頼性工学も探求されている，このよ うに信頼性工学においては，技術革新とその適用分野の領域を広げながら，システム全体の安全性・信頼性を確保するための 方策の検討がされている，近年では，豪雨などの異常気象や地震など自然災害による甚大な被害を踏まえた社会の信頼性，安 全性を確保するために，災害後の組織間連携など社会のレジリエンス向上の議論も始まっている.

信頼性工学部門委員会は, 設立当時から信頼性工学の理論やその応用を共通課題と捉えて, 材料疲労強度に限定せず多様な 学術領域の委員が参画し, 信頼性工学の理論とその応用についての研究を通して信頼性工学の発展に寄与している. 信頼性工 学の適用分野として, 金属材料疲労強度, 機械構造物, 土木建築構造物における信頼性設計や信頼性評価に関する研究やその 応用についての探求を進めている.

今回の連載講座においては, 信頼性工学部門委員会で, 近年活発に議論されている分野における確率モデルに焦点を当てて, 分野横断的に応用される信頼性工学の話題を提供できる下記テーマで構成した.

第 1 回 タイトル : 材料損傷・破壊問題への確率過程の応用

執筆者: 松田伸也 (香川大学), 合田公一 (山口大学)

第 2 回 タイトル：金属材料の統計的疲労特性に関するレビューおよび今後の展開

執筆者 : 中村裕紀 (豊田工業高等専門学校), 伊藤勉 (富山県立大学), 黒田雅利 (熊本大学), 境田彰芳 (明石工業高等専門学 校), 松田伸也 (香川大学), 松村隆 (電気通信大学), 酒井達雄 (立命館大学)

第 3 回 タイトル : 金属材料の静的強度特性值による $S-N$ 曲線の統計的推定と今後の展開

執筆者 : 伊藤勉 (富山県立大学), 中村裕紀 (豊田工業高等専門学校), 向山和孝 (大阪大学), 境田彰芳 (明石工業高等専門学 校), 中川雅央 (滋賀大学), 岡田憲司 (香川高等専門学校), 酒井達雄 (立命館大学)

第 4 回 タイトル : 破壊性状により変化する構造性能の確率的分析

執筆者 : 高橋利恵 (前橋工科大学)

第 5 回 タイトル：土構造物の地震・豪雨に対するリスク評価

執筆者 : 西村伸一 (岡山大学)

本連載講座の解説テーマは，材料の損傷破壊の確率過程による表現，本部門委員会と疲労部門委員会で収集している金属材 料疲労データベースを対象にした統計的分析，建築構造物への信頼性工学の応用，自然災害による土構造物のリスク評価とな っており，信頼性工学の基本的な理論や取り扱う対象に対する探究アプローチの方法論に触れることができる解説になってい る．特に，近年，自然災害に起因する被害の甚大化が懸念されており，それらに対する対策を講じる上で，自然災害に対する リスク評価は興味深い内容になっている．本講座が信頼性工学分野の技術者・研究者に限らず多くの関連分野の方々の参考に なれば幸いである。 


\title{
1. 材料損傷・破壊問題への確率過程の応用†
}

松田 伸也* 合田 公一**

\section{I: Application of Stochastic Processes for Damage and Fracture of Materials}

\author{
by
}

\section{Shinya MAtsudA* and Koichi GodA**}

\section{Key words:}

Markov process, Weibull distribution, CFRP, Porous ceramics, Cumulative fiber breakage, Damage tolerable property

\section{1 緒言}

工学分野における信頼性確保のためには，対象物の時 間とともに移り変わる現象を確率論的に理解する必要が ある。そのため, 信頼性工学の分野では確率過程論を用 い，その現象の推移が論じられてきた。信頼性工学部門 委員会では，過去に疲労き裂の不規則進展性や構造物の 損傷進展，経年劣化を扱う問題において，確率過程論を 応用した研究が多々報告されてきた。しかしながら，最 近の材料・構造信頼性分野において，確率過程に基づく 応用研究があまりみられなくなった，原因の一つとして， 近年のコンピュータ技術の目覚ましい発展により，高度 な解析ソフトが簡便に使えるようになったことが挙げら れる。その結果，解析手法の良否を考えずに利便性の良 いソフトを選び，解析の原理を知らないままブラックボ ックス化した中身を信用して結果を受入れることがしば しば見受けられる ${ }^{1)}$. 逆に言うと，解析ソフトに使われて いる基礎理論を理解せずに使うため，得られる結果の重 要性を見逃すことがある。具体的な事例として，モンテ カルロ法と数值計算ソフトを組合せた構造解析手法が存 在する。得られた解に対して，しばしば平均值や標準偏 差などを着目しがちであり，モンテカルロ法の確率変数 の意義や数值計算ソフトで使われる基礎理論の妥当性を 知らずに使用している.

確率過程の基礎理論を再認識することは，解析ソフト で得られる結果を唯一の解釈として受け入れることなく, また確率過程論の限界について見渡すことができるので, 信頼性工学を発展させる上で重要な課題であると言える。 さらに，近年では機械学習のアルゴリズムにマルコフ連 鎖モンテカルロ法(MCMC)など確率過程に基づく手法が 組み込まれている。ゆえに機械学習を構造解析手法に活 用する上でも大いに重要になろう。

以上を踏まえて本講座では, 材料の損傷および破壊問 題への確率過程論の適用性を解説する。初めに，モノリ シックセラミックスや炭素繊維の典型的なぜい性破壊問
題を取り上げ，確率過程論の適用による数式表現を論じ る. 次に, 多孔質セラミックスの累積微視損傷や炭素䋊 維強化プラスチック（CFRP）内の累積繊維破断に対して マルコフ過程を適用し，ぜい性破壊と累積損傷破壊との 相違について, 確率過程論の立場から論じる。

\section{2 基礎理論一マルコフ過程とワイブル分布一}

\section{$2 \cdot 1$ 最弱リンク説に基づくワイブル分布の導出}

セラミックスや炭素繊維のようなぜい性材料は欠陷や き裂が存在し，その中の最弱欠陥（最も大きい欠陥）を 起点として全体の破壊に至る。このとき，最弱欠陥のサ イズは試料によってばらつくので，その大きさに伴って 破壊強度は大きな変動を示す。このことは最弱リンク説 によって説明できる．Fig.1 に示すように， $n$ 個の輪が直 列に連結した 1 本の鎖を考える。これに一軸方向のみの

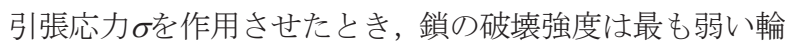
の破壊強度で決まる考え方を最弱リンク説と呼ぶ。まず 1 つの輪を取り上げ，一軸方向のみの引張応力 $\sigma か ゙$ 作用す ることを考える．輪の破壊確率を $F_{\text {ring }}(\sigma)$ とすると，輪に 生じるのまでに破壊しない確率は $1-F_{\text {ring }}(\sigma)$ である. 次に, Fig.1 に示寸 $n$ 個の輪からなる鎖に対して $\sigma$ を作用させた とき各輪に生じる応力はすべて $\sigma$ とする。すなわち，一様 な一軸引張応力状態を考える。このとき $n$ 個の輪がすべ て壊れない確率は鎖の壞れない破壊確率に等しい。ゆえ に鎖の破壊確率を $F_{\text {chain }}(\sigma)$ と寸れば，それぞれの $n$ 個の輪 の破壊しない確率の積となるため次式で表される.

$1-F_{\text {chain }}(\sigma)=\left[1-F_{\text {ring }}(\sigma)\right]^{n}=\exp \left[\ln \left\{1-F_{\text {ring }}(\sigma)\right\}^{n}\right]$

最弱リンク説では破壊強度の小さい輪が鎖の破壊強度 を決定するため, $F_{\text {ring }}(\sigma)<<1$ とすることができ，式(1)よ り $F_{\text {chain }}(\sigma)$ は次式で近似できる.

$F_{\text {chain }}(\sigma)=1-\exp \left\{-n F_{\text {ring }}(\sigma)\right\}$

これより， $F_{\text {chain }}(\sigma)$ は $F_{\text {ring }}(\sigma)$ だけでなく, 鎖を構成する 輪の数 $n$ にも依存することが理解できる. Weibull は

$\dagger$ 原稿受理 令和 3 年 3 月 9 日 Received Mar.9, 2021 @2 2021 The Society of Materials Science, Japan

* 正 会 員 香川大学 創造工学部 創造工学科 先端材料科学領域 †761-0396 高松市林町 Area in Advanced Mater. Sci., Faculty of Eng. and Design, Dept. of Eng. and Design, Kagawa Univ., Hayashi-cyo, Takamatsu, 761-0396.

** 正 会 員 山口大学 工学部 機械工学科 $\overline{7} 755-8611$ 宇部市常盤台

Dept. of Mech. Eng., Ymaguchi Univ., Tokiwadai, Ube, 755-8611. 
$F_{\text {ring }}(\sigma)$ として, $\left(\sigma / \sigma_{0}\right)^{m}$ を定義した. したがって, 式(2) を書き換えることで破壊確率 $F$ は,

$F(\sigma)=1-\exp \left\{-V / V_{0}\left(\sigma / \sigma_{0}\right)^{m}\right\}$

となり，ワイブル分布が表現される。ここで， $m$ は形状 母数, $\sigma_{0}$ は尺度母数であり, 分布の範囲や位置を特徵づ ける材料定数（ワイブルパラメータ）である。式(3)は, しばしば 2 母数ワイブル分布とも呼ばれる.また $n=V / V_{0}$

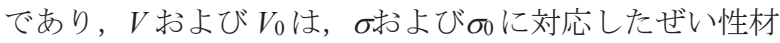
料の体積である。このようにワイブル分布には体積によ つて破壊強度が変わることが導出過程で組込まれてお り，いわゆる体積効果が表現されている.

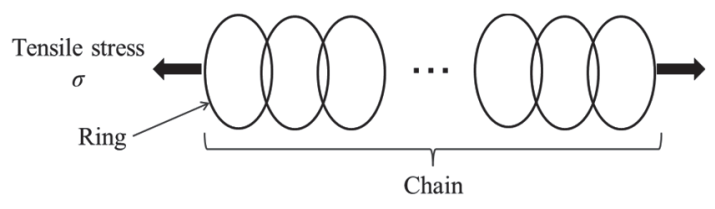

Fig.1 Weakest link model.

\section{$2 \cdot 22$ 状態 1 段過程に対する出生マルコフ過程}

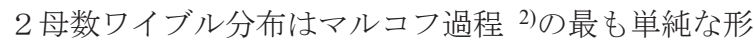
として数式表現できる. 同様に一軸引張応力のの下でぜい 性材料中に含まれる最弱欠陥からき裂が発生すると不安 定成長してぜい性破壊することを考える*1。このとき状態 遷移図 (マルコフグラフ) は Fig.2 で表される.ここで $\lambda(\sigma)$ は推移率であり，信頼性工学の分野では故障率と呼ばれ る。最弱欠陷を含む状態を $\mathrm{S}_{\mathrm{B} 0}$ とし, 材料が応力 $\sigma$ まで破 壊せず，その後の応力増分 $\Delta \sigma 内 て ゙$ 破壊した状態を $\mathrm{S}_{\mathrm{B} 1}$ と

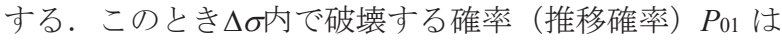
$\lambda(\sigma) \Delta \sigma$ あ゙あ.この材料は未破壊状態 $\mathrm{S}_{\mathrm{B} 0}$ または破壊状態 $\mathrm{S}_{\mathrm{B} 1}$ のどちらかにあり, 各状態の推移確率 $P_{00}, P_{11}$ は 1$\lambda(\sigma) \Delta \sigma, 1$ としてそれぞれ表される。また破壊は不可逆性 のため状態変化は $\mathrm{S}_{\mathrm{B} 0}$ から $\mathrm{S}_{\mathrm{B} 1}$ への一方向のみであり, $\mathrm{S}_{\mathrm{B} 1}$ から $\mathrm{S}_{\mathrm{B} 0}$ への推移確率 $P_{10}=0$ となる 2 状態 1 段過程である

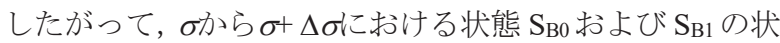
態確率 $P_{\mathrm{B} 0}, P_{\mathrm{B} 1}$ は式(4)で行列表現できる.

$\left(\begin{array}{l}P_{\mathrm{B} 0}(\sigma+\Delta \sigma) \\ P_{\mathrm{B} 1}(\sigma+\Delta \sigma)\end{array}\right)=\left(\begin{array}{l}P_{\mathrm{B} 0}(\sigma) \\ P_{\mathrm{B} 1}(\sigma)\end{array}\right)\left(\begin{array}{cc}1-\lambda(\sigma) \Delta \sigma & \lambda(\sigma) \Delta \sigma \\ 0 & 1\end{array}\right)$

$\Delta \sigma \rightarrow 0$ とするとき, 次の連立微分方程式が得られる.

$d P_{\mathrm{B} 0}(\sigma) / d \sigma=-\lambda(\sigma) P_{\mathrm{B} 0}(\sigma)$

$d P_{\mathrm{B} 1}(\sigma) / d \sigma=\lambda(\sigma) P_{\mathrm{B} 0}(\sigma)$

式(5-1)，(5-2)を境界条件 $P_{\mathrm{B} 0}(0)=1$ および $P_{\mathrm{B} 1}(\infty) \rightarrow 1$ の下 にそれぞれ解くと，

$P_{\mathrm{B} 0}(\sigma)=\exp \left[-\int_{0}^{\sigma} \lambda(\sigma) \mathrm{d} \sigma\right]$

$P_{\mathrm{B} 1}(\sigma)=1-\exp \left[-\int_{0}^{\sigma} \lambda(\sigma) \mathrm{d} \sigma\right]$

となる。ワイブル分布と等価にするためには推移率 $\lambda(\sigma)$ を式(7)のように，べき乗型関数とすればよい.

$\lambda(\sigma)=m \sigma^{m-1} / \sigma_{0}{ }^{m}$

※1 二軸または二軸均等引張応力下で 2 母数ワイブル分布が成立寸る 扱い ${ }^{3)}$ は，本稿では取り上げず，別の機会に議論する.
式(7)を式(6-1)，(6-2)に代入して計算すれば， $P_{\mathrm{B} 0 \text { および }}$ $P_{\mathrm{B} 1}$ はそれぞれ式(3)に示したワイブル分布の $V / V_{0}=1$ にお ける信頼度関数および累積分布関数と等価となる. なお, 推移率を指数型関数とすれば 2 重指数分布が得られる。

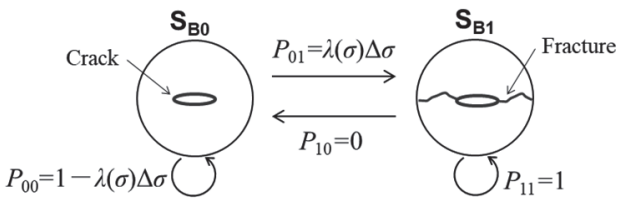

Fig.2 Markov graph (state transition diagram) for 2 states and 1 step.

\section{$2 \cdot 3$ ワイブル分布の解析事例}

Fig.3 に 4 点曲げ試験後の窒化ケイ素の破面および曲げ 強度 ${ }^{4)}$ のイブルプロットを例証する. セラミックスのよ うなぜい性材料では，破壊過程において，内在するき裂 を起点として一つの面内を放射状にき裂が進展する。そ の際に形成される表面は，平坦で鏡面状を呈するミラー 領域が形成される. その結果，巨視的な破面では，特徵 的な破壊起点（ミラー領域）と放射状の模様が観察され る（Fig.3(a)）。また強度分布は直線回帰できており，2母 数ワイブル分布に適合する (Fig.3(b)) 。ここで図中のワイ ブルパラメータは, 最小二乗法による直線回帰より求め ている。ただし，無限に大きなき裂は現実的に存在しな いため, さらにデータ数が多くなると強度の下限值が現 れる ${ }^{5)}$.この場合は, 3 母数ワイブル分布がよく適合する. したがって，一つの欠陥やき裂を起点として破壊するぜ い性材料は，最弱リンク説の仮説が適用できるため，そ の強度分布はワイブル分布に適合する。炭素繊維におい ても Fig.3 に類似した破面を呈し，引張強度はワイブル分 布に適合することがよく知られている ${ }^{6}$.
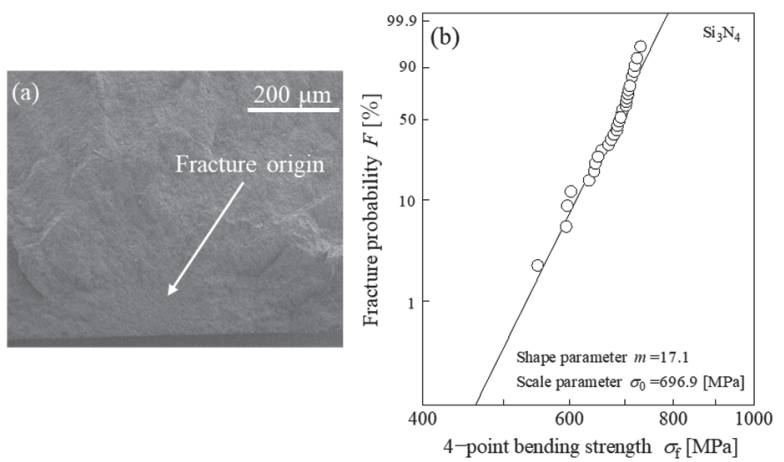

Fig.3 Results of a 4-point bending strength test for $\mathrm{Si}_{3} \mathrm{~N}_{4}$ :(a) the fracture surface and (b) Weibull plots of the strength.

\section{3 多孔質セラミックスの強度分布解析 (マルコフ過程の適用)}

多孔質セラミックス（以後，多孔体）は，破壊に至る 前に微視的な損傷を起こすために損傷許容性に優れてお り, 応力ーひずみ線図では非線形性が現れる ${ }^{7)}$. 本節では, 応力速度依存性を考慮した確定的なき裂進展モデルと累 積微視損傷を考慮したモデルによる $\mathrm{SiC}$ 系多孔体の 4 点 曲げ強度分布を解析する ${ }^{8)}$. 


\section{$3 \cdot 1$ 確定的なき裂進展を仮定した確率モデル}

安定き裂成長（Slow Crack Growth : SCG）則とワイブル 分布を組合せた確率モデルを示す. 時間 $t$ での応力 $\sigma(t)$ で 多孔体中の気孔（以後，初期き裂）から相互作用するこ となく独立してそれぞれモードIで SCG が起こることを 考える.き裂半長が $a$ のとき応力拡大係数 $K_{\mathrm{I}}$ は, $\phi \sigma(t) \sqrt{\pi a}$ （ $\phi$ : き裂形状係数）として表される. SCGの き裂進展速度 $v$ は実験的に,

$v=d a / d t=C\left(K_{\mathrm{I}} / K_{\mathrm{IC}}\right)^{n_{\mathrm{S}}}$

として表される。ここで $n_{\mathrm{s}}$ はき裂伝ぱ指数， $K_{\mathrm{IC}}$ は破壊 じん性值, $C$ は材料定数である. $t=0$ のとき初期き裂半 長を $a_{\mathrm{i}}$ とする. $t=t_{\mathrm{f}}$ のとき $a_{\mathrm{f}}$ まで安定成長して不安定破 壞するという条件の下で式(8)を積分すれば,

$$
\begin{aligned}
a_{\mathrm{i}}^{-\left(n_{\mathrm{S}}-2\right) / 2}-a_{\mathrm{f}}^{-\left(n_{\mathrm{S}}-2\right) / 2} & \approx a_{\mathrm{i}}^{-\left(n_{\mathrm{s}}-2\right) / 2} \\
& =\frac{n_{\mathrm{s}}-2}{2} C \alpha^{n_{\mathrm{S}}} \int_{0}^{t_{\mathrm{f}}} \sigma(t)^{n_{\mathrm{S}}} d t
\end{aligned}
$$

として計算される.ここで $\alpha=\phi \sqrt{\pi} / K_{\mathrm{IC}}$ である. 一般に セラミックスでは $n_{\mathrm{s}} \geq 20$ のため左辺の第 2 項を省略で きる。一方, SCG を起こさずに即時破壊する不活性強度 を $\sigma_{\mathrm{i}}$ とすれば $a_{\mathrm{i}}=\left(K_{\mathrm{IC}} /\left\{\phi \sigma_{\mathrm{i}} \sqrt{\pi}\right\}\right)^{2}$ と表現できる. また 一定負荷速度での破壊のため, $\sigma(t)=\dot{\sigma} t \quad(\dot{\sigma}$ : 応力速 度）と表され, 破壊強度 $\sigma \mathrm{r}$ は $\dot{\sigma} t_{\mathrm{f}}$ である.ゆえに等価静 的強度 $\sigma_{1}^{*}$ は,

$\sigma_{\mathrm{i}}^{*}=\left(A \sigma_{\mathrm{f}}^{n_{\mathrm{s}}+1} / \dot{\sigma}\right)^{1 /\left(n_{\mathrm{s}}-2\right)}$

として表現できる.ここで, $A=\left(n_{\mathrm{s}}-2\right) C \alpha^{2} /\left\{2\left(n_{\mathrm{s}}+1\right)\right\}$ で ある，多孔体中では，様々なサイズの初期き裂が存在し ており，そのうちの一つを起点として破壊すると仮定す る. 寸なわちのが式(3)のワイブル分布に従うと仮定し, $\sigma_{1}$ を $\sigma_{1}^{*}$ で置き換えると破壊確率 $F$ は,

$F\left(\sigma_{\mathrm{f}}, \dot{\sigma}\right)=1-\exp \left\{-\left(\sigma_{\mathrm{f}} / \hat{\sigma}_{0}\right)^{\hat{m}}\right\}$

と与えられる.ここで, $\hat{\sigma}_{0}=\sigma_{0}{ }^{\left(n_{\mathrm{s}}-2\right) /\left(n_{\mathrm{s}}+1\right)}(\dot{\sigma} / A)^{1 /\left(n_{\mathrm{s}}+1\right)}$ で あり， $V / V_{0}=1$ としている。また， $n_{\mathrm{s}} \geq 20$ のため $\hat{m}=m\left(n_{\mathrm{S}}+1\right) /\left(n_{\mathrm{s}}-2\right) \approx m$ と近似できる.

\section{$3 \cdot 2$ 累積微視損傷と応力分散を考慮した確率モデル}

SCG による確定的なき裂進展破壊ではなく，微視的な 損傷が累積（損傷許容性の発現）して破壊することを考 える. 具体的には, 応力のの増加とともに一つの結晶粒が 応力集中源となり, 隣接する結晶粒界のガラス相が SCG を起こした後に不安定成長して粒界が損傷する. その後, 次々と局所的に粒界損傷が起こり，損傷群 (クラスター) が形成される，そしてクラスターサイズがある臨界值に 到達したとき，多孔体が破壊すると仮定する．以上の機 構に対して累積損傷を確率過程で表すことを考え, その マルコフグラフを Fig.4 に示す. 無負荷の状態 $\mathrm{S}_{0}{ }^{*}$ におい て，すべての粒界は未損傷の状態にある。のの増加に伴い 一つずつ粒界が損傷していく過程のため, $i$ 個の粒界が損 傷した状態を $\mathrm{S}_{i}{ }^{*}$ と記し, その状態が故障率 $\mu_{i}$ の下で起こ るとする.したがって応力増分 $\Delta \sigma の$ 間に状態 $\mathrm{S}_{i}{ }^{*}$ から状態

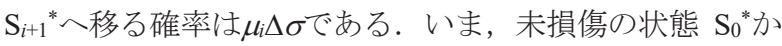

ら推移確率 $\mu_{0} \Delta \sigma$ で粒界が 1 つ損傷した状態 $\mathrm{S}_{1}{ }^{*}$ へ推移す る. 次に, 状態 $\mathrm{S}_{1}{ }^{*}$ から推移確率 $\mu_{1} \Delta \sigma$ でさらに粒界が 1 つ 損傷した状態 $\mathrm{S}_{2}{ }^{*}$ 一推移する.このように次々と連鎖的に 損傷が発生し, 最終的に $N_{\mathrm{c}}$ 個の粒界が損傷した状態 $\mathrm{S}_{N_{\mathrm{c}}}{ }^{*}$ のとき破壊を起こす，このとき各状態確率 $P_{i}^{*}(i=0,1,2$, $\left.\cdots, N_{\mathrm{c}}\right)$ は, 次の連立常微分方程式を満たす.

$d P_{0}^{*} / d \sigma=-\mu_{0} P_{0}^{*}$

$d P_{1}^{*} / d \sigma=\mu_{0} P_{0}^{*}-\mu_{1} P_{1}^{*}$

$d P_{2}^{*} / d \sigma=\mu_{1} P_{1}^{*}-\mu_{2} P_{2}^{*}$

$d P_{N_{\mathrm{c}}-1}^{*} / d \sigma=\mu_{N_{\mathrm{c}}-2} P_{N_{\mathrm{c}}-2}^{*}-\mu_{N_{\mathrm{c}}-1} P_{N_{\mathrm{c}}-1}^{*}$

$d P_{N_{\mathrm{c}}}^{*} / d \sigma=\mu_{N_{\mathrm{c}}-1} P_{N_{\mathrm{c}}-1}^{*}$

次に損傷周りの応力分担と推移率を考える. 多孔体の SEM 観察より結晶粒の配列は六方配列と近似した。これ より荷重分担係数 (応力集中係数) $K_{i}$ は, 破壊起点とな る 1 つの結晶粒に隣接する 6 つの結晶粒の粒界のみに応 力が分担されると考え, $1+i / 6$ として表現した. ゆえに推 移率 $\mu_{i}$ は，SCG 損傷を考慮した式(11)を用いて，

$\mu_{i}=-\frac{d}{d \sigma} \ln \left(1-F\left(\sigma K_{i}, \dot{\sigma}\right)\right)=\hat{m}\left(\frac{K_{i}}{\hat{\sigma}_{0}}\right)^{\hat{m}} \sigma^{\hat{m}-1}=L_{i} \sigma^{\hat{m}-1}$

として表現した. 式(12)および式(13)より，初期条件およ び収束条件として, $\sigma=0$ のとき $P_{0}{ }^{*}=1$ および $P_{k}{ }^{*}=0(k=1,2$, $\left.\cdots, N_{\mathrm{c}}-1\right), \sigma \rightarrow \infty$ のとき $P_{N \mathrm{c}}=1$ とすることで, 状態確率 $P_{0}{ }^{*}, P_{k}{ }^{*}$ および臨界クラスター発生確率 (破壊確率) $P_{N \mathrm{c}}{ }^{*}$ は，次のように計算される.

$$
\begin{aligned}
& P_{0}^{*}=\exp \left[-\left(\sigma / \hat{\sigma}_{0}\right)^{\hat{m}}\right] \\
& P_{k}^{*}=L_{0} L_{1} \cdots L_{k-1} \sum_{i=0}^{k} \frac{1}{\prod_{\substack{j=0 \\
j \neq i}}^{k}\left(L_{j}-L_{i}\right)} \exp \left[-\left(\frac{K_{i} \sigma}{\hat{\sigma}_{0}}\right)^{\hat{m}}\right] \\
& P_{N_{\mathrm{c}}}^{*}=1-L_{0} L_{1} \cdots L_{N_{\mathrm{c}}-1} \sum_{i=0}^{N_{\mathrm{c}}-1} \frac{1}{L_{i} \prod_{\substack{j=0 \\
j \neq i}}^{N_{\mathrm{c}}-1}\left(L_{j}-L_{i}\right)} \exp \left[-\left(\frac{K_{i} \sigma}{\hat{\sigma}_{0}}\right)^{\hat{m}}\right]
\end{aligned}
$$

式(16)の破壊確率曲線 $P_{N_{\mathrm{c}}}{ }^{*}$ は, 一定負荷速度の下, $N_{\mathrm{c}}$ を増 加させれば損傷許容効果のために確率曲線は高強度側に シフトし, 低確率側での立ち上がりが急速となる. 高破 壊確率になると $N_{\mathrm{c}}$ によらず 2 母数ワイブル分布に漸近し, 最終的には一致する. 一般のセラミックスを参考に形状 母数 $\hat{m}=10$ とした場合， $N_{\mathrm{c}}>10$ では一つのマスターカー ブに漸近する。このことは, 実際の破壊において粒界の 損傷は $N_{\mathrm{c}}>10$ と予想され, 本解が確率曲線の原分布にな りうることを示唆している. したがって $N_{\mathrm{c}}=10$ として多 孔体の破壊強度を予測した。

Fig.5 に各負荷速度に対する 4 点曲げ強度のワイブルプ ロットと式(11)および(16)による予測線図をそれぞれ示す. 各材料定数の決定は文献 8）を参考にしていただきたい. 曲げ強度は応力速度の低下に伴って低下した. $0.479 \mathrm{MPa} / \mathrm{s}$

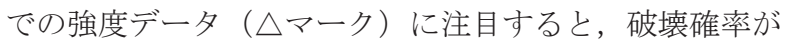
およそ $40 \%$ から分布の傾きが変化しており, 上に凸の形 
状を据える傾向を示した。これは，窒化ケイ素の強度分 布（Fig.3(b)）とは明らかに異なる。それに対して式(11) から予測した確率曲線は，強度の応力速度依存性は表現 できているが，直線であり，各負荷速度に対する実験值 からやや外れる傾向を示した。以上の結果より，一つの き裂から SCG により破壊するモデルでは，多孔体の破壊 過程を十分に説明できない。一方で，式(16)より予測した 確率曲線は，式(11)と比較して実験值を良く予測できてお り, 式(16)のモデルは妥当であると言える.このことから， 多孔体強度データの分布が曲線を示す理由は損傷許容性 による応力分配効果が影響していると考えられる．以上 より, マルコフ過程モデルを順問題として適用すれば多 孔体の損傷許容性を論じることができる.

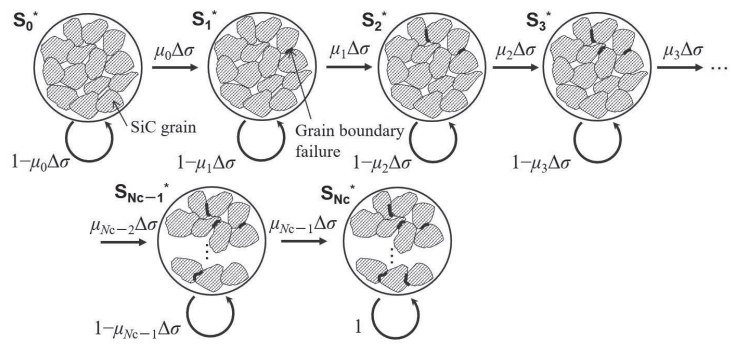

Fig.4 Markov graph of micro failure process in porous ceramics.

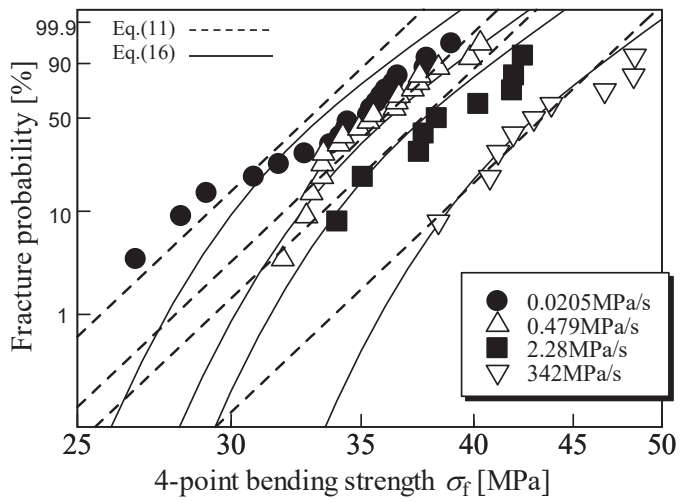

Fig.5 Weibull plots of the 4-point bending strength and curves predicted using Eqs. (11) and (16).

\section{CFRP内の繊維破断数の推定 （マルコフ過程による逆解析）}

長繊維系複合材料の強化材である炭素繊維やガラス 繊維は，単独の強度は優れているものの，そのばらつき も大きいことから確率論的に扱われることが多い。この ような確率変動を考慮した上で, 複合材料全体の強度予 測を行なう多数のモデリングが提案されてきた ${ }^{9)-15) . ~ こ ~}$ のうち, Chain-of-bundles モデル 99は長繊維系複合材料の 確率論的強度モデルの基本であり，多くの扱いに導入さ れている。しかし, Chain-of-bundles モデルは強度やその 分布を評価するものであり，繊維の破断過程を再現でき るものではない，本節では，少数繊維からなる CFRP の 強度データおよび単繊維試験によるワイブルパラメー タに基づき，マルコフ過程を用いて CFRP の繊維破断過 程の累積性を定量評価する ${ }^{16)}$.

\section{$4 \cdot 1$ 逆解析モデルの提示}

長繊維系複合材料の破壊過程は繊維破断やそれにとも なう界面はく離の蓄積をとおして進行する. 繊維破断点 からの応力回復域はマトリックスの弾性率や界面はく離 の規模によって決定され, 回復域の 2 倍の距離を無効長 さ9)と称し,これが Chain-of-bundles モデルにおける bundle 長さに相当する。界面はく離が生じないかまたはその規 模が小さければ応力集中によってクラスターと呼ばれる 繊維破断点の集まりが生成し，これが複合材料全体の破 壊源とされる。一方，セラミックス基複合材料で示され るように，界面はく離の規模が大きければ，応力集中の 規模は小さくクラスターは生じにくくなる．䋊維破断点 は個々に分散し，より累積数の多い破断過程を示すよう になるので，クラスター型と破断点分散型の破壊条件を 統一的にモデリングするのは困難である。そこで，応力 集中の有無を問わずに繊維の累積破断過程を定量的に評 価する手法を以下に提案する.

Fig.6 に長繊維系複合材料の破壊過程に関するマルコフ グラフを示す.まず無負荷の状態において, $N$ 本の繊維か ら成る複合材料内のすべての䋊維は未破断状態 $\mathrm{S}_{0}$ にある. 応力 $\sigma$ 負荷していくと $N$ 本中の最弱箇所で繊維破断が 生じるが，複合材料は破壊しない状態 $\mathrm{S}_{1}$ ，および 1 箇所 の破断点で複合材料全体が破壊に至る状態 $\mathrm{S}_{1 f}$ の 2 つの状

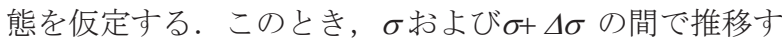
る確率として状態 $\mathrm{S}_{0}$ から $\mathrm{S}_{1}$ または $\mathrm{S}_{1 f}$ に推移する確率の 和を $\lambda_{1} \Delta \sigma\left(\lambda_{1}\right.$ : 推移率 $)$ とおくと，推移せずに $\mathrm{S}_{0}$ に留ま る確率は $1-\lambda_{1} \Delta \sigma$ である. $\mathrm{S}_{1 f}$ は破壊状態であり，Fig.6 に 示すように， $\mathrm{S}_{0} \rightarrow \mathrm{S}_{1 f}$ への吸収率を $\alpha_{1}$ とおき， $\mathrm{S}_{0} \rightarrow \mathrm{S}_{1}$ への 推移比をその排反事象として $\left(1-\alpha_{1}\right)$ とする．そして，同 様に $\mathrm{S}_{1} \rightarrow \mathrm{S}_{2 f}$ のように破断点が 2 つ連なったクラスターに よって複合材料全体が破壊する状態，および $\mathrm{S}_{1} \rightarrow \mathrm{S}_{2}$ のよ うに破断点が 2 つ存在しても破壊しない状態を設ける。 以降も $\mathrm{S}_{2} \rightarrow \mathrm{S}_{3 f}$ および $\mathrm{S}_{2} \rightarrow \mathrm{S}_{3}$ のように設定しながら, 同様 な状態推移を連続させる。このとき， $\mathrm{S}_{1} \rightarrow \mathrm{S}_{2 f}$ のようにク ラスターで壊れる状態, $\mathrm{S}_{3} \rightarrow \mathrm{S}_{4 f}$ のようにクラスターでな くてもその近傍で破断が生じたときに破壊する状態，あ るいは $\mathrm{S}_{2} \rightarrow \mathrm{S}_{3 f}$ のようにクラスターが存在しても応力集中 が及ばない離れた箇所で繊維破断が生じたときに破壊す る状態など，様々な破壊状態が想定される，以上のよう に表現すると, 本問題は離散的状態空間 $\{\mathrm{S}\}$ 内において状 態変化が $\mathrm{S}_{i-1} \rightarrow \mathrm{S}_{i}$ または $\mathrm{S}_{i-1} \rightarrow \mathrm{S}_{i f}$ が推移率 $\lambda_{i}(i=1,2,3, \ldots)$ の 下で起こるようなマルコフ過程となる. $\Delta \sigma \rightarrow 0$ とすると き, 各状態確率 $P_{i}(i=1,2,3, \ldots)$ は次の連立常微分方程式 を満足する.

$$
\begin{aligned}
& d P_{0} / d \sigma=-\lambda_{1} P_{0} \\
& d P_{1} / d \sigma=-\lambda_{2} P_{1}+\lambda_{1}\left(1-\alpha_{1}\right) P_{0} \\
& d P_{1 f} / d \sigma=\lambda_{1} \alpha_{1} P_{0} \\
& d P_{i} / d \sigma=-\lambda_{i+1} P_{i}+\lambda_{i}\left(1-\alpha_{i}\right) P_{i-1} \\
& d P_{i f} / d \sigma=\lambda_{i} \alpha_{i} P_{i-1}
\end{aligned}
$$


$d P_{(k+1) f} / d \sigma=\lambda_{k+1} P_{i}$

これより，1〜 $k$ 個の繊維破断点を含む破壊確率は，

$P_{f}=\sum_{i=1}^{k} P_{i f}$

となり，これに $P_{(k+1) f}$ が加わるとすべて破壊する．本解 析では $\lambda_{i}$ をワイブル分布の推移率で表現する.すなわち,

$\lambda_{i}=\frac{N L-(i-1) \cdot 2 \delta}{L_{0}} \cdot \frac{m \sigma^{m-1}}{\sigma_{0}{ }^{m}}(i=1,2,3, \ldots)$

と与える．ここで， $m ， \sigma 0$ はワイブル形状母数，尺度 母数, $L, L_{0}$ は繊維長さ, 標準繊維長さであり， $\delta$ は繊 維破断にともなう応力回復長さの 2 倍長を示し, 式 (19)は繊維破断が生じるごとに繊維の全長が減少する ことを示している。応力回復域では, $\operatorname{Cox}^{17)}$ の解のよ うにマトリックスを弾性体に仮定するとき $\delta$ は一定と なり, Kelly-Tyson モデル 18)のように弾完全塑性体を 仮定するとき $\delta$ は応力の関数であり $\sigma$ の増加とともに 増加する (本稿では Cox 解の結果を示す). また, 従 来の Harlow-Phoenix モデル 11)のように,これまでの確 率論的強度モデルでは繊維破断が生じると破断点周 りの応力集中を考慮した破断集積（クラスター）形成 を前提にするが，ここでは強度推定のモデリングを目 的としていないので，上述のようにクラスターも含め た様々な最終破壊状態を許容することができる。

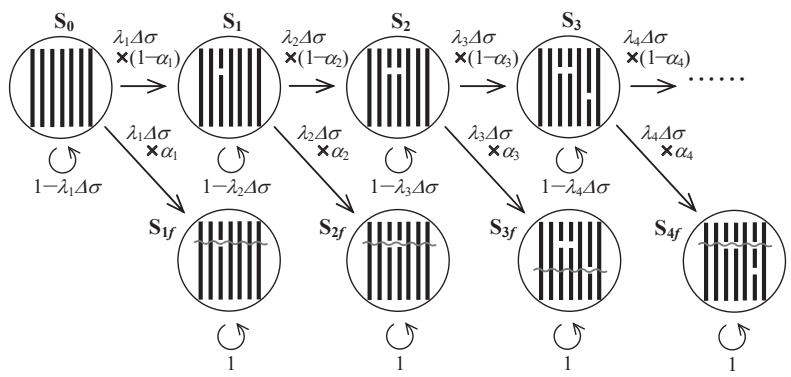

Fig.6 Markov graph of fiber breaking process in a long fiber-reinforced composite.

\section{$4 \cdot 2$ 逆解析モデルによる䋊維破断点累積性の評価}

炭素纎維(T300JB-3K, TORAY Co.)1, 2, 3, および4本か らなる束にエポキシ樹脂を浸透させて作製した少数緎 維試験片の引張強度データを対象とし, 式(17-1)から (17-6)を数值計算によってフィッティングさせた ${ }^{16)}$ 。そ の際，吸収率 $\alpha_{i}$ は式(18)の破壊確率曲線と実験データの 残差の二乗和が最小になるようにして決定した。このと き,ワイブルパラメータは $N=1$ で得られた結果より形状 母数 $m=7.39$ および尺度母数 $\sigma_{0}=3.22 \mathrm{GPa}$ とした。 また, 式(19)の $\delta$ は $0.11 \mathrm{~mm}$ として固定した.この值は Cox 解よ り得られる $90 \%$ 回復レベルに相当する.

Fig.7(a)に $N=2$ の結果を示す．まず $\alpha_{2} を 1$ に固定する と $P_{f}(k=1)$ とき $\alpha_{1}=0$ であった。すなわち，N=2 の CFRP は䋊維破断点が 1 つ発生しても壊れない。続いて $P_{f}(k$ $=2)$ のとき $\alpha_{2}=0.203$ であった。 このとき $\alpha_{1}=0$ および $\alpha_{3}=1$ と固定している。これから，試験片全体の $20.3 \%$ は 2 個 の繊維破断点を生じるときに破壊する.さらに, $P_{f}(k=3)$

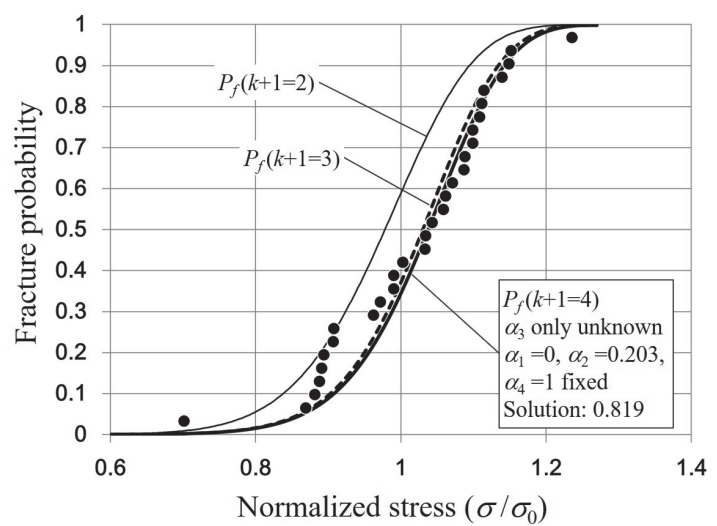

(a) Fitting to fracture probability data of CFRP strand with two fibers $(N=2)$

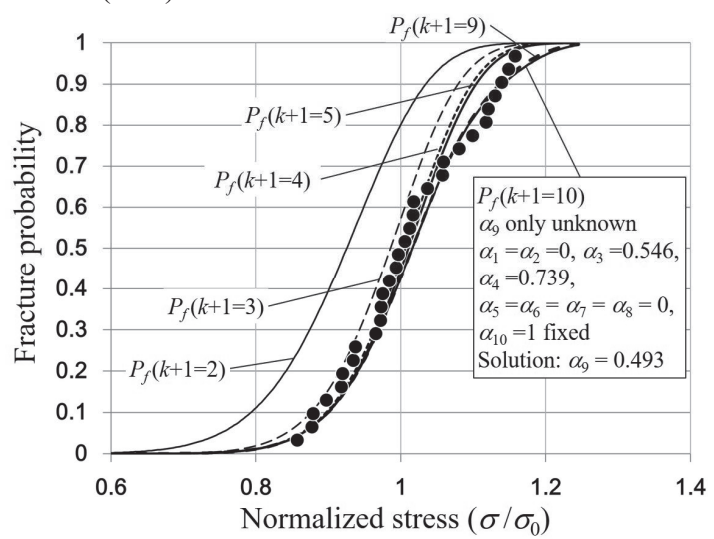

(b) Fitting to fracture probability data of CFRP strand with three fibers $(N=3)$

Fig.7 Fracture probabilities of CFRP strands and data fitting by proposed Markov process model.

とき $\alpha_{3}=0.819$ であった。このとき $\alpha_{1}=0, \alpha_{2}=0.203$ および $\alpha_{4}=1$ と固定している. これから, 先ほど壊れなかった残 り 79.7\%(=1-0.203)のうち, その $81.9 \%$ が 3 個の繊維破 断点を生じるときに破壊する. よって， $k=2$ または $k=3$ で壊れる試験片は $20.3 \%+79.7 \% \times 0.819$ ，すなわち $85.6 \%$ を占める.ささらに, $P_{f}(k=4)$ を試みたところ, 破壊曲線 は $P_{f}(k=3)$ とほぼ重なったが， $\alpha_{4}=0.468$ が得られた。こ れは試験片全体の $6.7 \%(=0.468 \times(100 \%-85.6 \%))$ が $k=4$ で 壊れることになる。最終的に全体の $0.3 \%$ の割合ではあ るが， $\alpha 7$ において 1 が得られた. すなわち，このCFRP は最大で 7 個の䋊維破断点が生じることを意味する. 平 均破断点数 $\bar{n}_{f}$ は

$\bar{n}_{f}=\sum_{i=1}^{k} i \cdot P_{i f}$

となり, 今回の結果では $\bar{n}_{f}=3.05$ が得られた. 換言する と, 2 本の繊維からなる CFRP 試験片は平均的に約 3 個 の破断点を有すると破壊に至る.ささらに, 得られた $\alpha_{1} \sim$ $\alpha_{7}$ を各 $P_{i f}$ に代入すれば, 引張応力の増加とともにどの ような割合で繊維破断点数が生成されていくか, 寸なわ ち繊維破断過程も推定することができる.

Fig.7(b)に $N=3$ の場合を示す. この場合は $\alpha_{1}=\alpha_{2}=0$ であ ったが, $\alpha_{3}=0.546$ および $\alpha_{4}=0.739$ が得られた。 これから， 3 本の䋊維からなる試験片は繊維破断点が 3 個および 4 
個で壊れる確率が $54.6 \%+45.4 \% \times 0.739$ ，すなわち全体の $88.2 \%$ 占める。 しかし, その後， $k=5,6,7$ では吸収率 $\alpha$ はすべて 0 であった. Fig.7(b)は $k=8$ の場合も 0 であるこ とを示している。ささらに $k=9$ を試みたところ，破壊曲線 は $P_{f}(k=8)$ とほぼ重なったが， $\alpha_{9}=0.493$ が得られた。これ は全体の $5.8 \%$ を占めており, 高強度領域をフィッティン グさせるには纎維破断の累積性が必要であることを意味 している.最終的に $\alpha_{10}$ において 1 が得られ， $\bar{n}_{f}=4.10$ で あった. 以上から，マルコフ過程モデルを逆解析手法と して適用することにより, CFRP の繊維破断過程を定量的 に論じることができる.

\section{5 おわりに}

本講座では，材料の損傷および破壊問題をターゲット として確率過程論の適用性を解説した。初めに，典型的 なぜい性破壊問題を取り上げ，最弱リンク説から導出さ れるワイブル分布は，確率過程論の適用によって数式表 現できることを示した．次に多孔質セラミックスの微視 的累積損傷や炭素繊維強化プラスチック（CFRP）内の累 積繊維破断に対してマルコフ過程を適用し，ぜい性破壊 と累積損傷破壊との相違を確率過程論の立場から論じた 確率過程論は，材料の損傷・破壊問題に限らず，幅広 い分野で適用されている．例えば，生物学において捕食 者非捕食者の系の動態を記述するために確率過程が適用 されている，また，昨今の COVID-19 の大流行により感 染症予測モデルである SIR モデル 19)を基盤とし，感染の 特徵が解析されている，その中で著者らは，マルコフ過 程に基づき COVID-19 の特徵を解析してきた．さらに信 頼性工学部門員会 確率過程応用研究分科会において COVID-19 の特徴を学術的に理解することを目的として, 委員会委員と議論してきた ${ }^{20)}$.

本講座を通じて確率過程は，分野や現象に捉われず対 象物の時間とともに移り変わる現象を確率論的に理解す る場合に有効な手法であり，確率論的な現象を見通しよ く表現できることを理解していただければ幸いである.

\section{参 考 文 献}

1) K. Goda, "Watashi no issatsu, Kagaku wo hagukumu", Journal of the Society of Mechanical Engineers, Vol. 121, p 44 (2018).

2) S. Karlin, "A first course in stochastic process", translated into Japanese by K. Sato and Y. Sato, pp. 193-237 (1974) Sangyo-Tosho.

3) Y. Matsuo, "On the Relative Coefficients of the Multiaxial Probability Distribution Function for Fracture", Bulletin of JSME, Vol. 24, pp. 495-500 (1981).

4) Chairman of Editorial Committee: H. Nakayama, "CERAMICS STRENGTH DATABASE VOL.1", p 1, (1996), The Society of Materials Science, Japan.

5) S. Matsuda and K. Ogi, "Effect analysis of loading rate on relationship between strength and flaw size of ceramics using probabilistic model on the basis of SCG concept", Transactions of the JSME, Vol. 83, p. 16-00369 (2017).

6) M. Herráez, A. Fernández, C. S. Lopes and C. González, "Strength and toughness of structural fibres for composite material reinforcement", Philosophical Transactions of the Royal Society A, Vol. 374, 20150274 (2016).

7) A. Suzuki and H. Baba, "Assessment of damage tolerance and reliability for ceramics", Journal of the Society of Materials Science, Japan, Vol. 50, pp. 290-296 (2001).

8) S. Matsuda and M. Takahashi, "Fracture strength distribution of porous ceramics under quasi-static load", Engineering Fracture Mechanics, Vol. 77, pp. 2601-2609 (2010).

9) B. W. Rosen, "Tensile failure of fibrous composites", AIAA Journal, Vol. 2, pp. 1985-1991 (1964).

10) C. Zweben, "Tensile failure analysis of fibrous composites", AIAA Journal, Vol. 6, pp. 2325-2331 (1968).

11) D. G. Harlow and S. L. Phoenix, "The chain-of-bundles probability model for the strength of fibrous materials I: Analysis and conjectures", Journal of Composite Materials, Vol. 12, pp. 195-214 (1978); ibid., "II: A numerical study of convergence", Vol. 12, pp. 314-334 (1978).

12) D. G. Harlow and S. L. Phoenix, "Probability distributions for the strength of composite materials I: two-level bounds", International Journal of Fracture, Vol. 17, pp. 347-372 (1981); ibid., "II: A convergent sequence of tight bounds", Vol. 17, pp. 601-630 (1981).

13) W. A. Curtin, "Theory of mechanical properties of ceramic-matrix composites", Journal of the American Ceramic Society, Vol. 74, pp. 2837-2845 (1991).

14) K. Goda, "Application of Markov process to chain-ofbundles probability model and lifetime distribution analysis for fibrous composites", Journal of the Society of Materials Science, Japan, Vol. 47, pp. 464-471, (1998)

15) K. Goda, "Markov process analysis for the strength of ceramic matrix composites reinforced with continuous fibers", Materials Science Research International, Vol. 8, pp. 87-92 (2002).

16) K. Goda and Y. Sawada, "Stochastic estimation of the number of fiber-break points in a CFRP by Markov process", Advanced Composite Materials, Vol. 29, pp. 569-586 (2020).

17) H. L. Cox, "The elasticity and strength of paper and other fibrous materials", British Journal of Applied Physics, Vol. 3, pp. 72-79 (1952).

18) A. Kelly and W. R. Tyson, "Tensile properties of fiber-reinforced metals: copper/tungsten and copper/ molybdenum", Journal of the Mechanics and Physics of Solids, Vol. 13, pp. 329-350 (1965).

19) W. O. Kermack and A. G. McKendrick, "A Contribution to the mathematical theory of epidemics". Proceedings of the Royal Society A, Vol. 115, pp. 700-721 (1927).

20) Subcommittee on Stochastic Processes and their Applications,https://material-reliability.wixsite.com/sto chastic-process (see web 2021.3.10). 